Article

\title{
Dual Doping of Silicon and Manganese in Hydroxyapatites: Physicochemical Properties and Preliminary Biological Studies
}

\author{
Katarzyna Szurkowska ${ }^{1}{ }^{1}$, Agata Drobniewska ${ }^{2}$ and Joanna Kolmas ${ }^{1, *} \mathbb{C}$ \\ 1 Department of Analytical Chemistry and Biomaterials, Analytical Group, Faculty of Pharmacy with \\ Laboratory Medicine Division, Medical University of Warsaw, ul. Banacha 1, 02-097 Warsaw, Poland \\ 2 Department of Environmental Health Sciences, Faculty of Pharmacy with Laboratory Medicine Division, \\ Medical University of Warsaw, ul. Banacha 1, 02-097 Warsaw, Poland \\ * Correspondence: joanna.kolmas@wum.edu.pl; Tel.: +48-22-572-07-55
}

Received: 4 July 2019; Accepted: 9 August 2019; Published: 12 August 2019

Abstract: Silicated hydroxyapatite powders enriched with small amounts of manganese $\left(\mathrm{Mn}^{2+}\right)$ cations were synthesized via two different methods: precipitation in aqueous solution and the solid-state method. The source of $\mathrm{Mn}^{2+}$ ions was manganese acetate, while silicon was incorporated using two different reagents: silicon acetate and sodium metasilicate. Powder X-ray diffraction (PXRD) analysis showed that the powders obtained via the precipitation method consisted of single-phase nanocrystalline hydroxyapatite. In contrast, samples obtained via the solid-state method were heterogenous and contaminated with other phases, (i.e., calcium oxide, calcium hydroxide, and silicocarnotite) arising during thermal treatment. The transmission electron microscope (TEM) images showed powders obtained via the precipitation method were nanosized and elongated, while solid-state synthesis produced spherical microcrystals. The phase identification was complemented by Fourier transform infrared spectroscopy (FTIR). An in-depth analysis via solid-state nuclear magnetic resonance (ssNMR) was carried out, using phosphorus ${ }^{31} \mathrm{P}$ single-pulse Bloch decay (BD) $\left({ }^{31} \mathrm{P} \mathrm{BD}\right)$ and cross-polarization $(\mathrm{CP})$ experiments from protons to silicon-29 nuclei $\left({ }^{1} \mathrm{H} \rightarrow\right.$ ${ }^{29} \mathrm{Si} \mathrm{CP}$ ). The elemental measurements carried out using wavelength-dispersive $\mathrm{X}$-ray fluorescence (WD-XRF) showed that the efficiency of introducing manganese and silicon ions was between $45 \%$ and $95 \%$, depending on the synthesis method and the reagents. Preliminary biological tests on the bacteria Allivibrio fisheri (Microtox®) and the protozoan Spirostomum ambiguum (Spirotox) showed no toxic effect in any of the samples. The obtained materials may find potential application in regenerative medicine, bone implantology, and orthopedics as bone substitutes or implant coatings.

Keywords: hydroxyapatite; manganese; silicon; biomaterials; infrared spectroscopy; nuclear magnetic resonance

\section{Introduction}

Among the calcium phosphates, hydroxyapatite (HA) $\left(\mathrm{Ca}_{10}\left(\mathrm{PO}_{4}\right)_{6}(\mathrm{OH})_{2}\right)$ has received considerable attention as a bone substitute material for orthopaedic and dental applications due to its strong affinity toward human mineralized tissues (bone and teeth) [1-4]. Biological apatite is nanocrystalline and contains various ions as impurities, mainly magnesium $\left(\mathrm{Mg}^{2+}\right)$ and carbonates $\left(\mathrm{CO}_{3}{ }^{2-}\right)$, with other trace elements in various amounts $\left(\mathrm{Zn}^{2+}, \mathrm{K}^{+}, \mathrm{Na}^{+}, \mathrm{Mn}^{2+}, \mathrm{SiO}_{4}{ }^{4-}, \mathrm{Cl}^{-}\right.$, and $\left.\mathrm{F}^{-}\right)[5-7]$. It should be noted that synthetic hydroxyapatites are highly susceptible to ionic substitution. Therefore, the introduction of various ions into the crystal structure of hydroxyapatite allows for obtaining material similar to bones and teeth. This is based on the concepts of biomimetics, where the greater the 
similarity existing between an implant and a tissue, the better they are expected to interact with each other $[8,9]$. It is important to note that ionic substitutions can change some physicochemical properties, such as the crystallographic lattice parameters, crystal morphology, and the degree of crystallinity. Substituting oxy-ions, (i.e., $\mathrm{SiO}_{4}{ }^{4-}, \mathrm{CO}_{3}{ }^{2-}$ ) and cations with various charges for the orthophosphates or structural hydroxyl groups and calcium ions, respectively, may lead to destabilization of the crystal lattice and a higher dissolution rate. Moreover, even a trace addition of some elements can significantly influence the thermal stability, solubility, or bioactivity of biomaterial, in vitro as well as in vivo [5-7].

Both manganese and silicon are classified as trace elements, with an average bone content of $1.7-3$ ppm and 100-150 ppm, respectively [10,11]. The divalent manganese ion has the ability to activate integrins, a family of receptors that facilitate cellular adhesion [12]. Stimulation of bone cell adhesion, viability, and proliferation has a beneficial effect on the interaction of the implant with the host bone tissue $[13,14]$. Manganese is also a cofactor in enzymes, such as glycosyltransferases, involved in the remodelling of the extracellular matrix present in bone and cartilage [15]. Studies have shown that manganese supplementation in ovariectomized rats inhibits bone loss [16]. A key role for manganese in maintaining normal bone mass has been suggested, indicating its deficiency as a likely cause of osteoporosis [17,18]. Other mechanisms of manganese's beneficial effects on bone tissue metabolism include osteocalcin stimulation, increased alkaline phosphatase activity and collagen type I production $[13,14,19]$. Syntheses of hydroxyapatites substituted with various amounts of manganese were carried out, from trace amounts (a few ppm) to $11.9 \mathrm{wt} \%[14,16,19-24]$. However, it is important to note that in vitro studies on osteoblast cells showed significantly better results for lower manganese contents [16,19], while a Mn content of $1 \mathrm{wt} \%$ was regarded as high and caused drastically lower cell viability [24].

In contrast to manganese, silicon has a well-established position as a bioactivity-improving additive for bone biomaterials $[11,25,26]$. Carlisle's landmark studies have defined the appropriate level of silicon required for the proper development and mineralization of osseous tissue $[27,28]$. The mechanism of silicon action is based on the positive impact of orthosilicic acid on the synthesis of type-I collagen $[29,30]$. Moreover, in the presence of orthosilicic acid in the medium, osteoblast-like MG-63 cells exhibit increased alkaline phosphatase activity and osteocalcin synthesis $[29,30]$. Furthermore, exposure to silicon has a stimulatory effect on the differentiation, proliferation, and activity of osteoblasts [31-34]. Thus, partial replacement of the hydroxyapatite phosphate group by silicate ions should further improve the biological activity of the bioceramic. Numerous syntheses of Si-substituted hydroxyapatite (Si-HA) were carried out, introducing up to $5 \mathrm{wt} \%$ of $\mathrm{Si}$, which corresponds to the introduction of 1.7 moles of Si per mole of HA [35-47]. According to the research, to ensure phase uniformity of the obtained material along with optimal bioactivity, substitution should not exceed 1 mole of Si per mole of HA [36,37]. The beneficial effect of silicon substitution in HA has been demonstrated in numerous in vitro and in vivo experiments. High in vitro activity was confirmed by apatite precipitation when the samples were soaked in simulated body fluid (SBF), as well as in studies on osteoblasts, osteoclasts, and osteosarcoma cell cultures [37-41]. In vivo studies have shown faster bone remodelling in Si-HA samples, which additionally testifies to the osteoconductive properties of Si-HA [42-47].

The aim of the current study was to synthesize novel hydroxyapatite material, co-substituted with manganese (II) and silicate ions. Based on the previously quoted results [16,19,36,37], substitutions of $0.017 \mathrm{wt} \%$ of manganese and $1.98 \mathrm{wt} \%$ of silicon were planned for the current research. Synthesis was carried in two different ways: via precipitation and solid-state method. Moreover, two silicate sources were used, to compare the effectiveness of substitution for various synthesis conditions. This work focused on the structure and physico-chemical properties of the dual-doped hydroxyapatites, which were characterized using transmission electron microscopy (TEM), powder X-ray diffractometry (PXRD), Fourier transform infrared spectroscopy (FTIR,) solid-state nuclear magnetic resonance (ssNMR), and wavelength dispersive X-ray fluorescence (WD-XRF). Preliminary acute toxicity tests were also conducted. 


\section{Materials and Methods}

\subsection{Preparation of Samples}

Synthesis of the materials was performed using two different methods (the precipitation method and the solid-state method) with two different sources of silicon $\left(\mathrm{Na}_{2} \mathrm{SiO}_{3}\right.$ or $\left.\mathrm{Si}\left(\mathrm{CH}_{3} \mathrm{COO}\right)_{4}\right)$. The planned samples, with nominal composition Ca9.997 $\mathrm{Mn}_{0.003}\left(\mathrm{PO}_{4}\right)_{5.3}\left(\mathrm{SiO}_{4}\right)_{0.7}(\mathrm{OH})_{1.3}$ and intended $(\mathrm{Ca}+\mathrm{Mn}) /(\mathrm{P}+\mathrm{Si})$ molar ratio of 1.67 , are summarized in Table 1. Regardless of the silicon source, $\mathrm{Si}$ was introduced into hydroxyapatite in the form of orthosilicate $\mathrm{SiO}_{4}{ }^{4-}$ ions. In the case of metasilicate ions, hydrolysis occurred under the reaction conditions.

Table 1. Various parameters of the obtained samples.

\begin{tabular}{|c|c|c|c|c|}
\hline & $\mathrm{Mn}, \mathrm{SiO}_{3}-\mathrm{HAw}$ & $\mathrm{Mn}, \mathrm{SiO}_{4}-\mathrm{HAw}$ & $\mathrm{Mn}, \mathrm{SiO}_{3}-\mathrm{HAd}$ & $\mathrm{Mn}, \mathrm{SiO}_{4}$-HAd \\
\hline Synthesis method & \multicolumn{2}{|c|}{ Precipitation } & \multicolumn{2}{|c|}{ Solid-state } \\
\hline Silicon source & $\mathrm{Na}_{2} \mathrm{SiO}_{3}$ & $\mathrm{Si}\left(\mathrm{CH}_{3} \mathrm{COO}\right)_{4}$ & $\mathrm{Na}_{2} \mathrm{SiO}_{3}$ & $\mathrm{Si}\left(\mathrm{CH}_{3} \mathrm{COO}\right)_{4}$ \\
\hline Parameter $a(\AA)^{\mathrm{a}}$ & 9.424 & 9.433 & 9.418 & 9.415 \\
\hline Parameter $c(\AA)^{\mathrm{a}}$ & 6.882 & 6.875 & 6.886 & 6.896 \\
\hline Mn content $(w t \%)$ & $0.0086 \pm 0.0004$ & $0.0110 \pm 0.0004$ & $0.0076 \pm 0.0003$ & $0.0080 \pm 0.0004$ \\
\hline Si content $(w t \%)$ & $1.217 \pm 0.005$ & $1.512 \pm 0.003$ & $1.819 \pm 0.003$ & $1.879 \pm 0.004$ \\
\hline Mn substitution efficiency (\%) & 50.59 & 64.71 & 44.71 & 47.06 \\
\hline Si substitution efficiency $(\%)$ & 61.48 & 76.34 & 91.88 & 94.90 \\
\hline$(\mathrm{Ca}+\mathrm{Mn}) /(\mathrm{P}+\mathrm{Si})$ molar ratio & $1.54 \pm 0.05$ & $1.59 \pm 0.04$ & $1.61 \pm 0.03$ & $1.62 \pm 0.05$ \\
\hline
\end{tabular}

Precipitation synthesis was carried out at room temperature. Stoichiometric amounts of $\mathrm{Ca}\left(\mathrm{NO}_{3}\right)_{2} \cdot 4 \mathrm{H}_{2} \mathrm{O}$ and $\left(\mathrm{CH}_{3} \mathrm{COO}\right)_{2} \mathrm{Mn}$ were dissolved in $400 \mathrm{~mL}$ of distilled water in a flask under constant stirring. A Si-containing solution $\left(\mathrm{Na}_{2} \mathrm{SiO}_{3}\right.$ or $\mathrm{Si}\left(\mathrm{CH}_{3} \mathrm{COO}\right)_{4}$ dissolved in $50 \mathrm{~mL}$ of distilled water) and a P-containing solution $\left(\left(\mathrm{NH}_{4}\right)_{2} \mathrm{HPO}_{4}\right.$ dissolved in $50 \mathrm{~mL}$ of distilled water) were added dropwise to the Ca-Mn precursor solution using separate burettes. The $\mathrm{pH}$ was adjusted to approximately 10 using concentrated ammonia solution. The resultant precipitate was allowed to rest for $24 \mathrm{~h}$ for ageing. The precipitates were then filtered through a $0.8 \mu \mathrm{m}$ pore size membrane filter under reduced pressure and rinsed several times with distilled water until the filtrate reached $\mathrm{pH}$ 7. This step was aimed at washing away residual reagents and soluble reaction products. The obtained precipitates were dried at $130^{\circ} \mathrm{C}$ for $24 \mathrm{~h}$ and then ground in an agate mortar for physico-chemical and biological characterization.

For the solid-state synthesis, $\mathrm{CaCO}_{3},\left(\mathrm{CH}_{3} \mathrm{COO}\right)_{2} \mathrm{Mn},\left(\mathrm{NH}_{4}\right)_{2} \mathrm{HPO}_{4}$, and $\mathrm{Na}_{2} \mathrm{SiO}_{3}$ or $\mathrm{Si}\left(\mathrm{CH}_{3} \mathrm{COO}\right)_{4}$ were used. The weighed substrates were ground in a ball mill and were pressed into tablets using a hydraulic press (pressure force 10 tons). The key step in the solid-state synthesis was sintering the tablets in the muffle furnace (Czylok FCF2,5SH, Jastrzębie-Zdrój, Poland) using the following temperature program: heating to $400{ }^{\circ} \mathrm{C}$ for $8 \mathrm{~h}$, heating to $700{ }^{\circ} \mathrm{C}$ for $8 \mathrm{~h}$, heating to $1000{ }^{\circ} \mathrm{C}$ for $8 \mathrm{~h}$, then allowed to cool. To prevent the oxidation of $\mathrm{Mn}^{2+}$ ions, heating was carried out in an argon atmosphere. After the thermal treatment, the tablets were crushed in an agate mortar and the obtained powder was then subjected to further analysis.

\subsection{Sample Characterization}

The synthesized materials were analyzed via X-ray powder diffractometry (PXRD) using a Bruker D8 DISCOVER diffractometer (Bruker, Karlsruhe, Germany) with a $\mathrm{Cu}$ anticathode $(\lambda=1.54 \AA$ ). The scans were run from $20^{\circ}$ to $70^{\circ}$, with a step size of $0.024^{\circ}$, a step time of $4 \mathrm{~s}$, and a locked, coupled (theta-theta) geometry. Stoichiometric HA (inorganic crystal structure database ICSD \#00-009-0432) was used as the reference pattern. On the basis of the diffraction patterns, the parameters of the unit 
cell ( $a$ and $c$ ) were estimated. The Scherrer equation (1) was used to calculate the crystal sizes of the samples synthesized by the precipitation method [48]:

$$
\mathrm{d}=\frac{0.94 \lambda}{\beta \cos \theta}
$$

where

$\mathrm{d}$-crystallite size $(\mathrm{nm})$

$\lambda$-radiation wavelength ( $\mathrm{nm}$ )

$\beta$-the peak full width at half maximum intensity (radians)

$\theta$-the diffraction angle of the corresponding reflex $\left(^{\circ}\right)$.

The reflections at approximately $25.8^{\circ}$ and $39.9^{\circ}$ were chosen for the calculation.

A JEOL JEM-1400 transmission electron microscope (TEM, Jeol LTD, Tokyo, Japan) with an accelerating voltage of $80 \mathrm{kV}$ was used to observe the morphology of the obtained powders. In order to prepare the samples for TEM analysis, they were suspended in ethanol and then dropped on a copper grid covered with Formvar.

Elemental analysis of the synthesized apatites was carried out via the WD-XRF method in the solid state, using tablets made of samples carefully triturated with microcrystalline cellulose. In order to determine the percentage weight of manganese and silicon in the samples, a standard curve of the signal-to-element concentration was made. The standard curve for each element consisted of five measurement points, while the blank sample was a tablet made of pure microcrystalline cellulose. To ensure uniform distribution of the standard in the tablet mass, the cellulose was mixed with a calculated amount of the standard solution, which was later evaporated. The cellulose was compressed into a tablet using a hydraulic press. Each measurement was carried out in triplicate using a WD-XRF ARL ADVANT'X spectrometer (Thermo Electron Corp., Waltham, MA, USA). The (Ca + Mn)/(P+Si) ratio of the samples was determined using energy-dispersive $\mathrm{X}$-ray spectroscopic microanalysis (EDS INCA Energy TEM, Oxford Instruments, Abingdon, UK; Ca and P contents measured from six spots and then averaged).

The chemical composition of the samples was investigated using Fourier transform infrared spectroscopy (FTIR, Perkin Elmer, Waltham, MA, US). The samples were ground with $\mathrm{KBr}$ in an agate mortar and then analyzed from 4000 to $400 \mathrm{~cm}^{-1}$ using a Perkin Elmer Spectrum 1000 spectrometer. Spectra were obtained within 30 repetitions (scans) with a resolution of $2 \mathrm{~cm}^{-1}$.

Solid-state NMR experiments on ${ }^{31} \mathrm{P}$ and ${ }^{29}$ Si nuclei were performed using a Bruker WB 400 spectrometer (Bruker, Karlsruhe, Germany). The following experiments were carried out: ${ }^{31} \mathrm{P}$ single-pulse Bloch decay $\left({ }^{31} \mathrm{P} \mathrm{BD}\right)$ and cross-polarization from protons to silicon-29 nuclei $\left({ }^{1} \mathrm{H} \rightarrow{ }^{29} \mathrm{Si}\right.$ $\mathrm{CP}$ ). The samples were spun at 7 and $5 \mathrm{kHz}$ for the ${ }^{31} \mathrm{P}$ and ${ }^{29} \mathrm{Si}$ experiments, respectively, at the magic angle spinning (MAS), using $\mathrm{ZrO}_{2}$ rotors. The ${ }^{31} \mathrm{P}$ and ${ }^{29} \mathrm{Si}$ chemical shifts were referenced to external $85 \%$ orthophosphoric acid and tetramethylosilane (TMS), respectively.

Preliminary toxicity tests were performed using two tests: Microtox®and Spirotox. Two different suspensions were prepared, i.e., 1 and $2 \mathrm{mg} / \mathrm{mL}$. The Microtox@test was based on the lyophilized luminescent bacteria Allivibrio fischeri. The suspended samples were incubated for $15 \mathrm{~min}$ with the bacteria in disposable glass cuvettes and then the light output of the samples was measured in the Microtox®M500 analyser (Osprey Scientific, Edmonton, AB, Canada). All samples were run in duplicate. For the control, $2 \% \mathrm{NaCl}$ was used.

The protozoan Spirostomum ambiguum was used in the Spirotox test, which was performed in polystyrene multiwell plates according to the standard protocol [49]. In each well, 10 organisms were placed together with the suspended materials. The samples were incubated in the dark at $25^{\circ} \mathrm{C}$ for 24 and $48 \mathrm{~h}$. Then, a dissection microscope was used to analyze the lethal response or deformation of the $S$. ambiguum cell. The sample was tested in triplicate in each acute toxicity test (Microtox $($ and Spirotox); however, the tests were repeated (performed twice). Tyrode's solution was used as a control. 


\section{Results and Discussion}

\subsection{PXRD, TEM, and Elemental Analysis Results}

The PXRD patterns of the powders synthesized by the precipitation method $\left(\mathrm{Mn}, \mathrm{SiO}_{3}-\mathrm{Haw}\right.$, and $\mathrm{Mn}, \mathrm{SiO}_{4}-\mathrm{HAw}$ ) revealed the presence of poorly crystallized hydroxyapatite (see Figure 1). The reflections were very wide and weakly resolved, and some of them were too broad to be detected. Therefore, it may be suggested that the materials were nanocrystalline. The calculations based on the Scherrer equation allowed the crystal size to be estimated for the $\mathrm{Mn}, \mathrm{SiO}_{4}-\mathrm{HAw}$ and $\mathrm{Mn}, \mathrm{SiO} 3-\mathrm{HAw}$ nanocrystalline samples. The lengths of crystallites were $11 \pm 2 \mathrm{~nm}$ and $13 \pm 3 \mathrm{~nm}$, while the widths were $6 \pm 2 \mathrm{~nm}$ and $7 \pm 2 \mathrm{~nm}$, respectively.

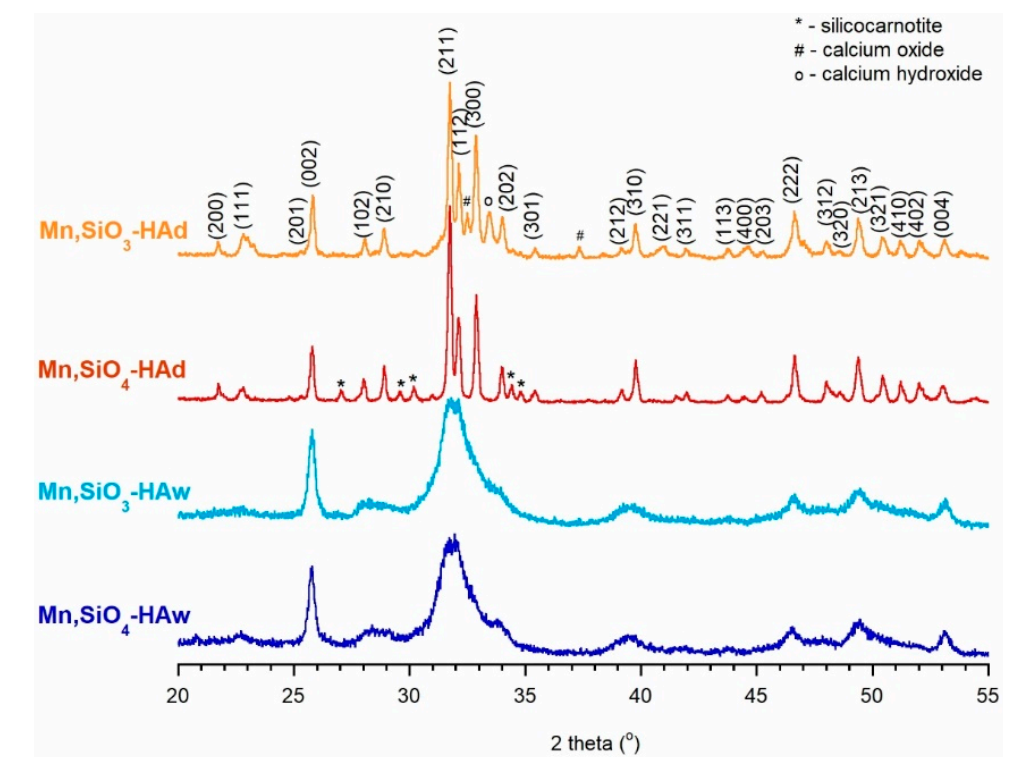

Figure 1. PXRD patterns of the analyzed samples.

In contrast, in the PXRD diffractograms of the samples prepared using the solid-state method ( $\mathrm{Mn}, \mathrm{SiO}_{3}-\mathrm{HAd}$ and $\mathrm{Mn}, \mathrm{SiO}_{4}-\mathrm{HAd}$ ), narrow and well-resolved reflections were observed (see Figure 1). It is worth noting that the solid-state method of synthesis led to extra reflections on the diffractogram patterns of both samples. In the $\mathrm{Mn}, \mathrm{SiO}_{3}-\mathrm{HAd}$ pattern, the additional reflections at ca $32.45^{\circ}$, $37.45^{\circ}$, and $33.42^{\circ}$ may be attributed to calcium oxide and calcium hydroxide, respectively [50,51]. The results of Rietveld refinement showed that the sample $\mathrm{Mn}, \mathrm{SiO}_{3}-\mathrm{HAd}$ contained $3 \mathrm{wt} \%$ of $\mathrm{CaO}$ and $2 \mathrm{wt} \%$ of $\mathrm{Ca}(\mathrm{OH})_{2}$. On the other hand, the $\mathrm{Mn}, \mathrm{SiO}_{4}-\mathrm{HAd}$ pattern presented additional reflections at approximately $34.7^{\circ}, 30.2^{\circ}, 29.6^{\circ}, 26.9^{\circ}$, and $34.4^{\circ}$ that originated mainly from silicocarnotite $\left(\mathrm{Ca}_{5}\left(\mathrm{PO}_{4}\right)_{2} \mathrm{SiO}_{4}\right)$ [51,52]. It should be noted that during calcination, in both cases, the obtained hydroxyapatites partially decomposed. This is usually promoted by non-stoichiometry and the presence of impurities or additives, i.e., substituted ions. Andreev et al. [51] suggested that silicocarnotite is a material produced during high-temperature calcination of calcium phosphates with silicon sources. According to the Rietveld analysis, the $\mathrm{Mn}, \mathrm{SiO}_{4}-\mathrm{HAd}$ sample contained $5 \mathrm{wt} \%$ of silicocarnotite (JCPDS \#40-393).

The parameters ( $a$ and $c$ ) of the apatitic crystal unit cell of the obtained samples (see Table 1 ) were found to be slightly different from those of stoichiometric HA ( $a=9.432 \AA$ and $c=6.881 \AA)$, but it is difficult to find any regularities. According to the literature, the introduction of silicon ions should cause a decrease in the parameter $a$ and an increase in the parameter $c$, while manganese substitution should reduce both parameters [5-7]. There was a distinct decrease in parameter $a$ and an increase in parameter $c$ in both of the solid-state-synthesized samples. On the other hand, the unit cell parameters of the samples obtained via the precipitation method did not change significantly. 
The TEM micrographs of the samples obtained via the precipitation method $\left(\mathrm{Mn}, \mathrm{SiO}_{4}-\mathrm{HAw}\right.$ and $\mathrm{Mn}, \mathrm{SiO}_{3}-\mathrm{HAw}$ ) are shown in Figure 2. The powders were nanosized, and the crystals were elongated and needle-shaped. This is in clear accordance with the literature where both the addition of manganese and silicate ions caused the formation of needle-like crystals [5-7]. Moreover, the crystals exhibited a high tendency to agglomerate, and therefore it was difficult to measure crystal sizes. However, we observed that the $\mathrm{Mn}, \mathrm{SiO}_{4}-\mathrm{HAw}$ sample was characterized by smaller crystals compared to the $\mathrm{Mn}, \mathrm{SiO}_{3}-\mathrm{Haw}$ sample. As shown in Figure 2, the crystals were heterogenous and differed significantly in size, while the calculation using the Scherrer equation shows the average crystal size. Synthesis in the solid state caused the formation of large crystal agglomerates, with sizes of up to approximately $0.5 \mu \mathrm{m}$. During the long heat treatment, the crystals formed a spherically shaped mould. As in the case of precipitation synthesis, the sample obtained from silicon acetate $\left(\mathrm{Mn}, \mathrm{SiO}_{4}-\mathrm{HAd}\right)$ appeared to have smaller crystals. However, the difference was not as pronounced as in the precipitation method.

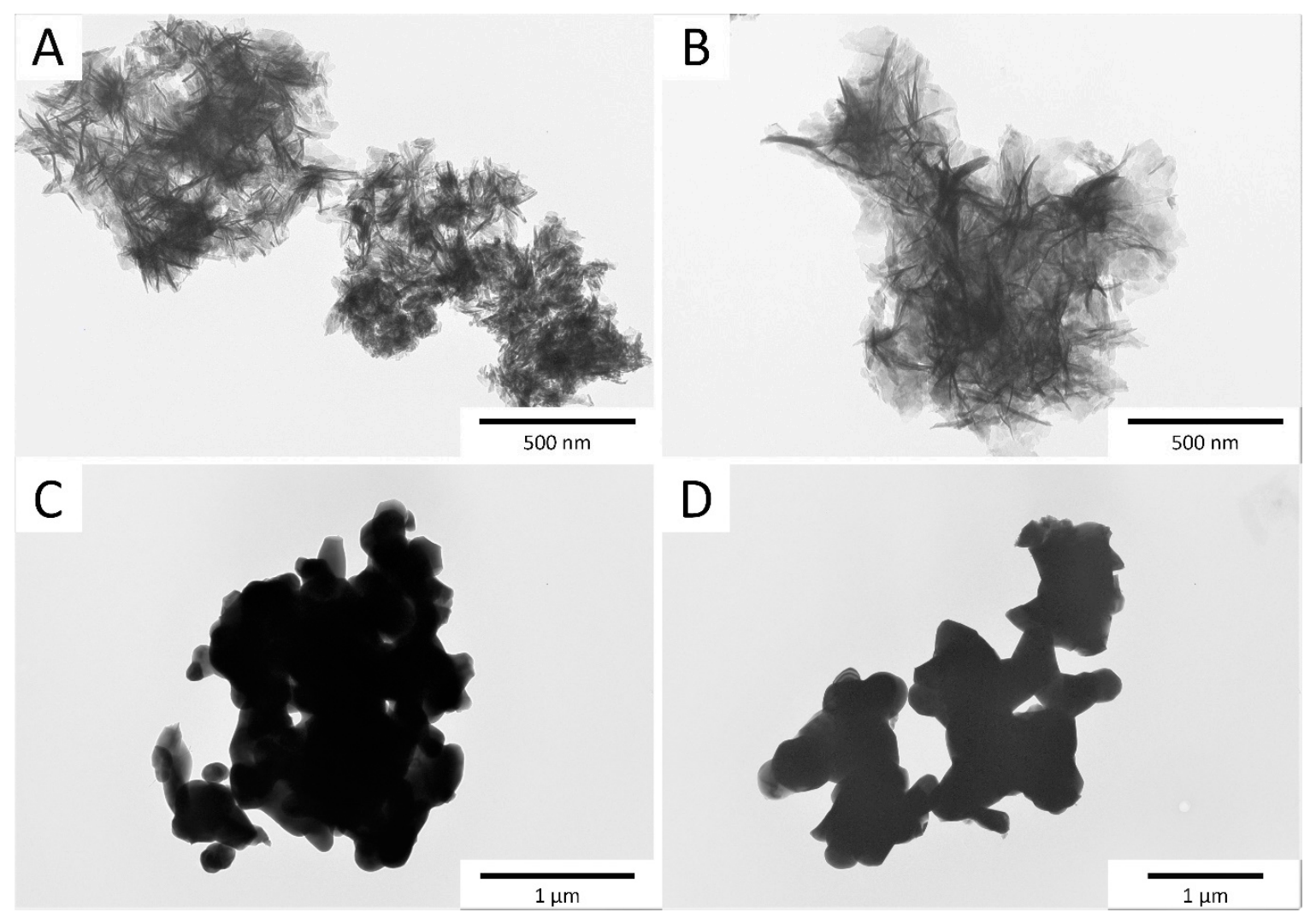

Figure 2. TEM images of the analyzed samples: (A) $\mathrm{Mn}, \mathrm{SiO}_{4}-\mathrm{HAw},(\mathbf{B}) \mathrm{Mn}, \mathrm{SiO}_{3}-\mathrm{HAw},(\mathbf{C}) \mathrm{Mn}, \mathrm{SiO}_{4}-\mathrm{Had}$, and (D) $\mathrm{Mn}_{2} \mathrm{SiO}_{3}-\mathrm{HAd}$.

The Mn and Si content in each of the samples prepared using the two methods are presented in Table 1. In the $\mathrm{Mn}, \mathrm{SiO}_{3}-\mathrm{HAw}$ and $\mathrm{Mn}, \mathrm{SiO}_{4}-\mathrm{HAw}$ samples, manganese concentrations reached 50.6\% and $64.7 \%$ of the nominal values, respectively. For the samples synthesized via the solid-state method, the Mn content was slightly lower $(44.7 \%-47.1 \%$ of the nominal concentration). It is worth noting that substitution with $\mathrm{Mn}^{2+}$ ions was not trivial and ran with low efficiency. Recent works on the synthesis of hydroxyapatites enriched in manganese indicate that the substitution takes place within a limited range (up to $10 \mathrm{~mol} \%$ ) [22,24]. In addition, the thermal treatment of Mn-HA causes the decomposition of material at a fairly low temperature $\left(600^{\circ} \mathrm{C}\right)$ [21,24]. In contrast, the silicon substitution efficiency in $\mathrm{Mn}, \mathrm{SiO}_{3}-\mathrm{HAd}$ and $\mathrm{Mn}, \mathrm{SiO}_{4}-\mathrm{HAd}$ was significantly higher (91.9\% and $94.9 \%$, respectively) than in the samples produced using precipitation $\left(61.5 \%\right.$ and $76.4 \%$ of the nominal value for $\mathrm{Mn}_{2} \mathrm{SiO}{ }_{3}-\mathrm{HAw}$ and $\mathrm{Mn}, \mathrm{SiO}_{4}-\mathrm{Haw}$, respectively). According to the literature, silicate ions can be located both inside the crystals (in the crystal's core) and on the surface in the so-called hydrated surface layer. During 
the synthesis using the precipitation method, nanocrystals with an expanded surface layer were obtained [48]. Repeated washing of the obtained precipitates may lead to a partial loss of silicates, and thus lower substitution efficiency. In addition, silicates may "compete" with carbonates in the substitution of orthophosphates in the apatitic lattice. During the solid-state synthesis, carbonate ions contamination was easily removed by thermal decomposition. It is also worth mentioning that simultaneous substitution with silicate and manganese ions may be hindered due to the differences in ionic radii of $\mathrm{Ca}^{2+} / \mathrm{Mn}^{2+}(100$ vs. $67 \mathrm{pm})$ and $\mathrm{PO}_{4}{ }^{3-} / \mathrm{SiO}_{4}{ }^{4-}(238$ vs. $240 \mathrm{pm})$. Verification of such a hypothesis requires further research (especially PXRD detailed analysis).

\subsection{FTIR Spectroscopy}

The FTIR spectra of the synthesized samples are shown in Figure 3. The absorption stretching bands in the region 1200-960 $\mathrm{cm}^{-1}$ may be assigned to the typical orthophosphate vibrations for hydroxyapatites. Phosphate bending bands $\left(v_{4}\right)$ were observed at 570 and $603 \mathrm{~cm}^{-1}$ [53-57]. A weak band of structural hydroxyl groups at $3570 \mathrm{~cm}^{-1}$ was clearly detectable in the $\mathrm{Mn}, \mathrm{SiO}_{3}-\mathrm{HAd}$ and $\mathrm{Mn}, \mathrm{SiO}_{4}$-HAd spectra, while in the $\mathrm{Mn}, \mathrm{SiO}_{3}-\mathrm{HAw}$ and $\mathrm{Mn}, \mathrm{SiO}_{4}-\mathrm{HAw}$ spectra, it was partially obscured by a broad band in the $3700-2500 \mathrm{~cm}^{-1}$ region. This broad band and the band at $1640 \mathrm{~cm}^{-1}$ were due to moisture in the samples synthesized via the precipitation method, and they corresponded to the stretching and bending vibrations of water, respectively. As expected, in the spectra of the samples obtained via the solid-state method, the bands from water were very weak, whereas the band located at $630 \mathrm{~cm}^{-1}$, corresponding to librational vibration of structural hydroxyl groups, was easily detectable [53-57]. In addition, weak bands at 1455 and $1418 \mathrm{~cm}^{-1}$ observed in the $\mathrm{Mn}, \mathrm{SiO}_{3}-\mathrm{HAw}$ spectrum, was attributed to carbonates (types $\mathrm{A}+\mathrm{B}$ and $\mathrm{B}$, respectively) [54].

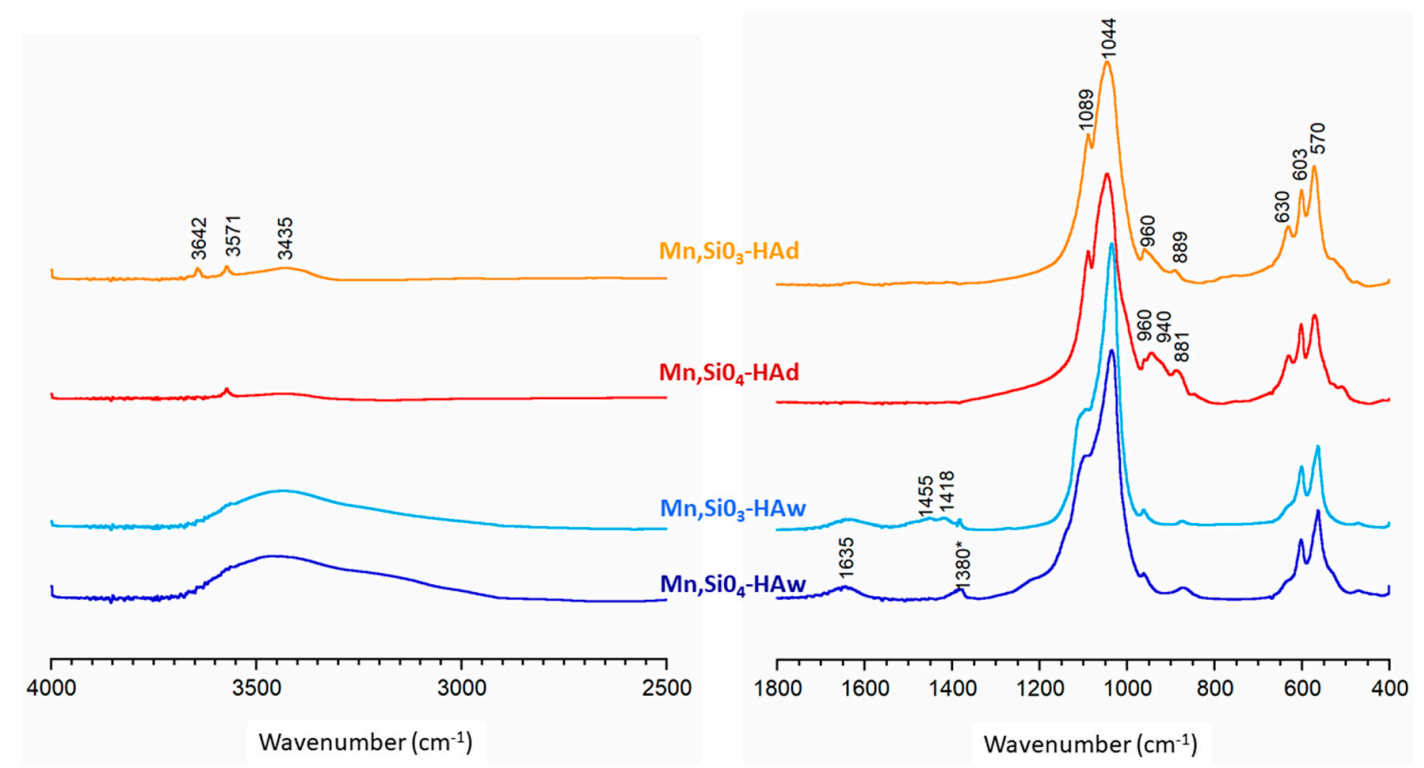

Figure 3. FTIR transmission spectra of the analyzed samples.

It should be noted that during the synthesis, carbonates may be easily substituted for hydroxyl groups (type A) and orthophosphates (type B) [5-7]. The presence of carbonate bands was consistent with the lowest silicon content in this sample, since carbonates and orthosilicate ions compete for the same sites in the apatite structure. Moreover, in the spectrum of the $\mathrm{Mn}, \mathrm{SiO}_{3}-\mathrm{HAd}$ sample, a narrow and weak band at $3642 \mathrm{~cm}^{-1}$ was probably due to the $\mathrm{OH}$ groups of calcium hydroxide, which, according to the PXRD pattern, represented a secondary phase present after synthesis via the solid-state method. Spectra for both the samples obtained using the solid-state method contained additional bands in the $940-840 \mathrm{~cm}^{-1}$ region. These were consistent with the literature and can be attributed to silicates $[35-37,58,59]$. The band located at approximately $880-890 \mathrm{~cm}^{-1}$, visible in all samples, 
can be assigned to $\mathrm{Si}-\mathrm{O}$ vibration modes of $\mathrm{SiO}_{4}{ }^{4-}$ tetrahedra groups, while a band at $940 \mathrm{~cm}^{-1}$ in the $\mathrm{Mn}, \mathrm{SiO}_{4}$-HAd sample corresponds to vibrations of the $\mathrm{Si}-\mathrm{OH}$ bond. Indirect evidence for the substitution of orthosilicate ions into hydroxyapatite was observed as low intensity hydroxyl bands at approximately $3570 \mathrm{~cm}^{-1}$ and $630 \mathrm{~cm}^{-1}$. According to the reaction mechanism proposed by Gibson et al. [35], substitution of the trivalent orthophosphate group by a tetravalent orthosilicate group results in the loss of a hydroxyl group in order to maintain the charge balance. It is worth noting that the complex group of silicate bands is diminutive in the spectra of the $\mathrm{Mn}, \mathrm{SiO}_{4}-\mathrm{HAw}$ and $\mathrm{Mn}, \mathrm{SiO}_{3}-\mathrm{HAw}$ samples. This can be explained by the lower silicon content and the lower degree of crystallinity of the precipitated samples. In addition, the silicate bands may be obscured by signals from phosphates and carbonates occurring at similar frequencies [54,56].

\section{3. ${ }^{31} \mathrm{P}$ and ${ }^{29}$ Si MAS NMR Spectroscopy}

The phosphorus-31 resonance spectra of all the powders acquired using the BD technique are shown in Figure 4. As expected, all the spectra exhibited a quite narrow signal at about 2.75-3.15 ppm, which according to the literature, can be attributed to orthophosphate groups located in well-ordered apatitic crystals [60-62]. It should be noted that the lines obtained from the powders synthesized using precipitation were significantly wider than those obtained from the solid-state-synthesized samples. Moreover, all obtained spectra are slightly asymmetric, which suggests the presence of additional signals. Deconvolution revealed additional lines for all the spectra (see Figure 5 for examples and Table 2). In the $\mathrm{Mn}, \mathrm{SiO}_{4}-\mathrm{HAw}$ and $\mathrm{Mn}, \mathrm{SiO}_{3}-\mathrm{HAw}$ samples, apart from the main signal, two additional signals were detected: one at $\approx 2.30 \mathrm{ppm}$ and another at $\approx 5.30 \mathrm{ppm}$. According to the literature, these additional lines come from the disordered structure of the hydrated surface layer $[60,62]$. The signals at $\approx 2.14-2.33 \mathrm{ppm}$ and $\approx 5.10-5.35 \mathrm{ppm}$ detected in all the spectra may be assigned to protonated $\left(\equiv \mathrm{PO}_{\mathrm{x}} \mathrm{H}\right)$ and unprotonated $\left(\equiv \mathrm{PO}_{\mathrm{x}}\right)$ surface groups (where $\equiv$ stands for a link to the crystal surface), respectively [60-62]. Due to overlap of the ${ }^{31} \mathrm{P}$ NMR lines, it is not straightforward to determine the contribution of ${ }^{31} \mathrm{P}$ nuclei from the disordered phase to the total ${ }^{31} \mathrm{P}$ reservoir. However, based on the deconvolution of the spectra, it can be estimated that in the $\mathrm{Mn}, \mathrm{SiO}_{3}-\mathrm{HAw}$ and $\mathrm{Mn}, \mathrm{SiO}_{4}$-Haw samples, $42.5 \%-45.5 \%$ of the phosphorus- 31 nuclei come from ${ }^{31} \mathrm{P}$ nuclei from the disordered phase.

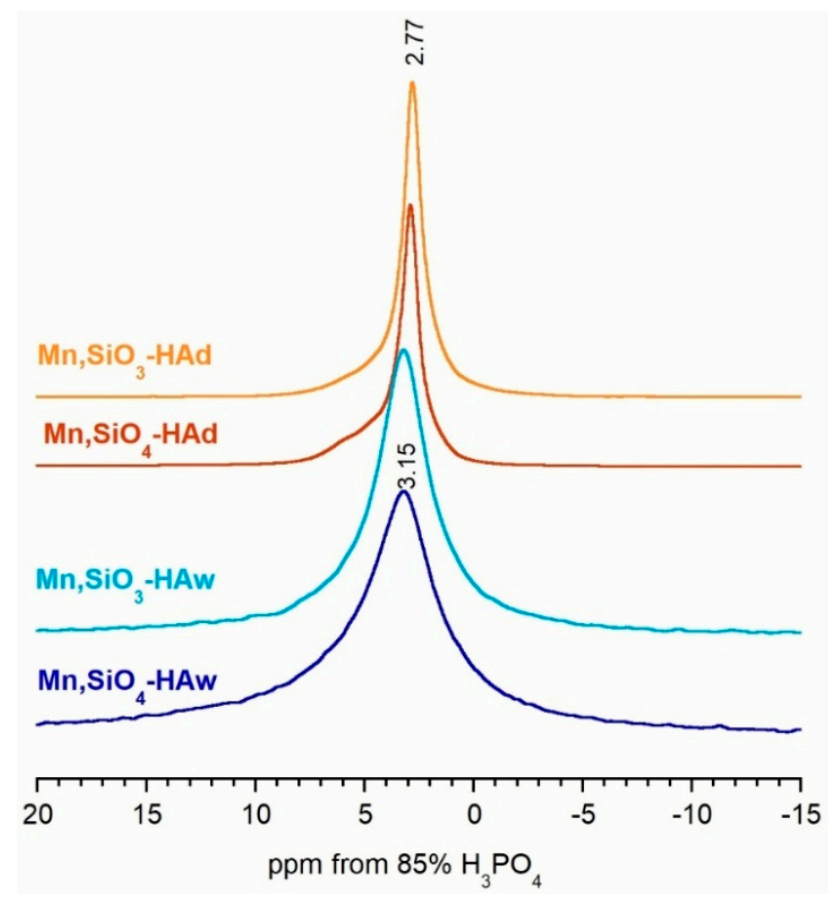

Figure 4. ${ }^{31} \mathrm{P}$ BD NMR spectra of the analyzed samples. 

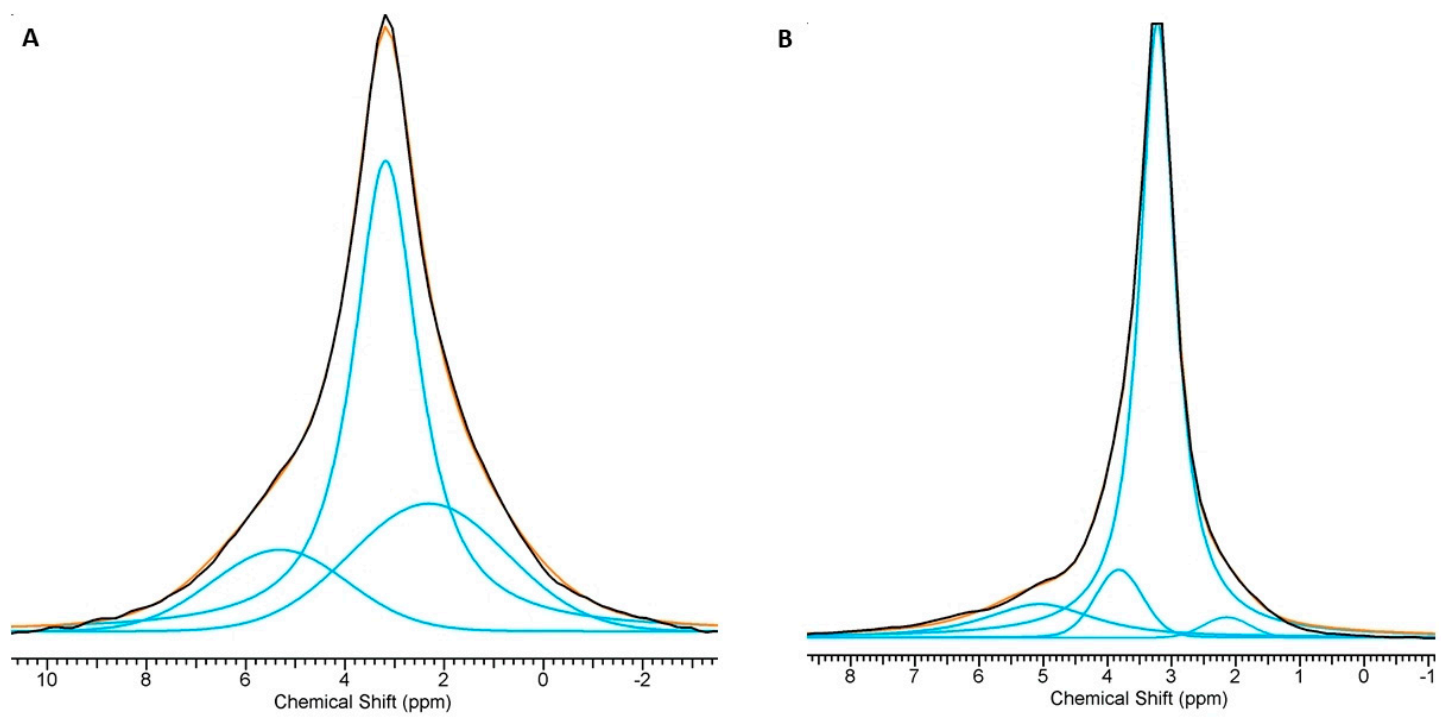

Figure 5. Representative deconvolution of the ${ }^{31} \mathrm{P}$ BD NMR spectra: (A) $\mathrm{Mn}, \mathrm{SiO}_{4}-\mathrm{Haw}$ and (B) $\mathrm{Mn}, \mathrm{SiO}_{4}$-HAd.

Table 2. NMR deconvolution results for the ${ }^{31} \mathrm{P}$ BD NMR experiments (FWHM-full width at half maximum).

\begin{tabular}{|c|c|c|c|c|}
\hline & Assignments & Chemical Shift (ppm) & FWHM (Hz) & Percentage of Total Area (\%) \\
\hline \multirow{3}{*}{$\mathrm{Mn}, \mathrm{SiO}_{4}-\mathrm{HAw}$} & $\equiv \mathrm{PO} \times \mathrm{H}$ & 2.31 & 606 & 27.4 \\
\hline & main & 3.18 & 256 & 57.4 \\
\hline & $\equiv \mathrm{POx}$ & 5.31 & 523 & 15.1 \\
\hline \multirow{3}{*}{ 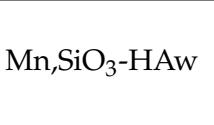 } & $\equiv \mathrm{POxH}$ & 2.25 & 640 & 22.3 \\
\hline & main & 3.22 & 248 & 54.5 \\
\hline & $\equiv \mathrm{POx}$ & 5.28 & 551 & 23.2 \\
\hline \multirow{4}{*}{$\mathrm{Mn}, \mathrm{SiO}_{4}-\mathrm{HAd}$} & $\equiv \mathrm{PO} \times \mathrm{H}$ & 2.14 & 138 & 2.4 \\
\hline & main & 3.22 & 108 & 77.0 \\
\hline & $\equiv \mathrm{POx}$ & 5.10 & 329 & 12.1 \\
\hline & silicocarnotite & 3.85 & 142 & 7.5 \\
\hline \multirow{4}{*}{$\mathrm{Mn}, \mathrm{SiO}_{3}-\mathrm{HAd}$} & $\equiv \mathrm{POxH}$ & 2.33 & 145 & 4.2 \\
\hline & main & 3.15 & 111 & 78.5 \\
\hline & $\equiv \mathrm{POx}$ & 5.35 & 316 & 15.2 \\
\hline & silicocarnotite & 4.12 & 156 & 2.1 \\
\hline
\end{tabular}

As presented in Figure 5 and Table 2, the $\mathrm{Mn}, \mathrm{SiO}_{4}-\mathrm{HAd}$ and $\mathrm{Mn}, \mathrm{SiO}_{3}-\mathrm{HAd}$ spectra revealed three additional lines. Apart from the main signal at 3.15-3.22 ppm and the weak and broad lines (from protonated $\left(\equiv \mathrm{PO}_{\mathrm{x}} \mathrm{H}\right)$ surface groups and from unprotonated $(\equiv \mathrm{PO})$ surface groups), an additional line at $\approx 3.85-4.12 \mathrm{ppm}$ was easily detected. Its contribution is not very significant $(7.5 \%$ and $2.1 \%$ for $\mathrm{Mn}, \mathrm{SiO}_{4}$-HAd and $\mathrm{Mn}, \mathrm{SiO}_{3}$-HAd samples, respectively). It can probably be assigned to the silicocarnotite phase [51]. The PXRD pattern of $\mathrm{Mn}, \mathrm{SiO}_{3}-\mathrm{HAd}$ did not contain reflections from silicocarnotite, but this may be explained by the small amount of this crystalline phase. Its presence in the $\mathrm{Mn}, \mathrm{SiO}_{3}-\mathrm{HAd}$ sample was confirmed using a ${ }^{31} \mathrm{P}$ BD NMR experiment.

It should be noted that the resonance lines originating from the phosphorus-31 nuclei in the disordered phase (especially in the hydrated surface layer) were relatively weak (up to $16.4 \%$ ), suggesting that the $-\mathrm{POH}$ groups at the surface were relatively sparse. This is in accordance with the presumption that the hydrated surface layer of apatitic crystals synthesized under high-temperature conditions (via the solid-state method) is exiguous.

The standard ${ }^{1} \mathrm{H} \rightarrow{ }^{29} \mathrm{Si} \mathrm{CP}$ MAS spectra are presented in Figure 6. Because of the low content of $\mathrm{Si}$ in the materials, the spectra presented significant noise, despite the long accumulation time. 
In all the spectra, a resonance line at approximately -72.7 to $-73.3 \mathrm{ppm}$ was predominant and can be assigned to a $\mathrm{Q}^{0}$ structure of silicates located within the crystal core [63-66]. It should be noted that in the $\mathrm{Mn}, \mathrm{SiO}_{4}-\mathrm{HAw}$ spectrum, only one signal (-73.3 ppm) could be detected. However, in the $\mathrm{Mn}, \mathrm{SiO}_{3}-\mathrm{HAd}, \mathrm{Mn}, \mathrm{SiO}_{3}-\mathrm{Haw}$, and $\mathrm{Mn}_{2} \mathrm{SiO}_{4}-\mathrm{HAd}$ spectra, the resonance in this region was very broad and a second line (at approximately -69.3 to $-70.3 \mathrm{ppm}$ ) was clearly visible. It could possibly be associated with the $\mathrm{Q}^{0}$ silicates located at the crystal surface. Surprisingly, in the spectra of the $\mathrm{Mn}, \mathrm{SiO}_{3}-\mathrm{HAw}$ and $\mathrm{Mn}, \mathrm{SiO}_{3}-\mathrm{HAd}$ samples, multiple broad and poorly resolved lines occurred in the region -88.0 to $-100.1 \mathrm{ppm}$. According to the literature, these correspond to $\mathrm{Q}^{3} / \mathrm{Q}^{4}$ and are characteristic of non-crystalline silica species $[36,64]$. Therefore, we can conclude that the introduction of silicates into the apatitic crystal lattice seems to be more limited with sodium metasilicate as a source than with silicon acetate.

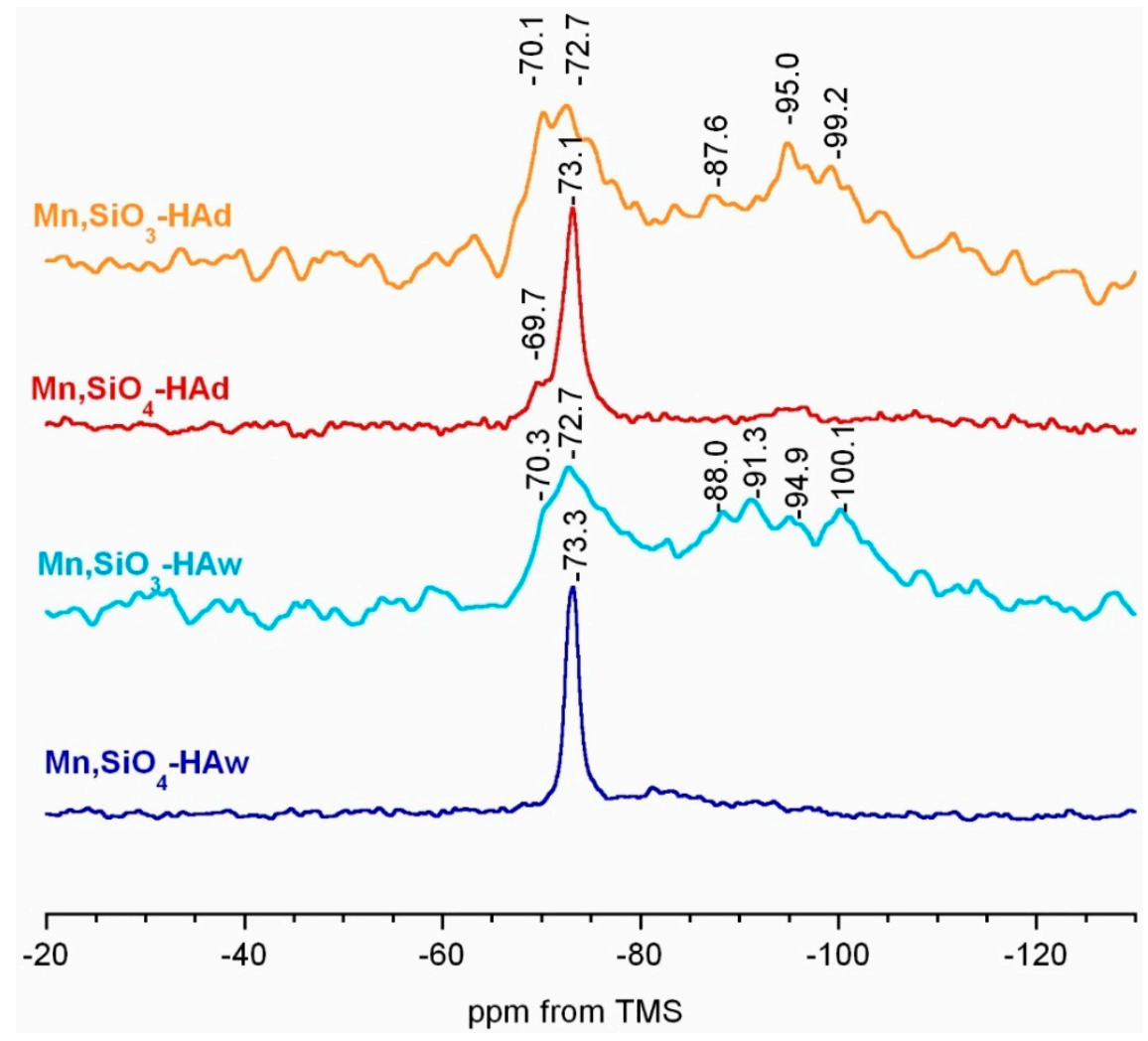

Figure 6. ${ }^{29} \mathrm{Si}$ CP MAS NMR spectra of the analyzed samples.

\subsection{Preliminary Biological Tests}

In order to evaluate the acute toxicity, the luminescent bacterium A. fisheri (Microtox $($ ) and protozoan S. ambiguum (Spirotox) tests were used. Although manganese and silicon are essential trace elements, it was planned to check the toxicity of the Mn and Si content in the nanocrystals $\left(\mathrm{Mn}, \mathrm{SiO}_{4}-\mathrm{HAw}\right.$ and $\mathrm{Mn}, \mathrm{SiO}_{3}-\mathrm{HAw}$ ) and microcrystals (see Table 3). The obtained samples were observed to be non-toxic in both tests. These preliminary studies showed that the silicon and manganese contents of $1.22-1.88 \mathrm{wt} \%$ and $0.0076-0.0110 \mathrm{wt} \%$, respectively, in HAs were completely neutral, and the obtained powders can be treated as promising materials for future biological investigations, i.e., cytotoxicity and biocompatibility. 
Table 3. Toxicity of the synthesized powders in Microtox®and Spirotox tests.

\begin{tabular}{|c|c|c|c|c|}
\hline \multirow{2}{*}{ Sample } & \multicolumn{2}{|c|}{ Microtox@(15 min-PE) ${ }^{1}$} & \multicolumn{2}{|c|}{ Spirotox ${ }^{2}$} \\
\hline & $1.0 \mathrm{mg} / \mathrm{mL}$ & $2.0 \mathrm{mg} / \mathrm{mL}$ & $1.0 \mathrm{mg} / \mathrm{mL}$ & $2.0 \mathrm{mg} / \mathrm{mL}$ \\
\hline $\mathrm{Mn}, \mathrm{SiO}_{4}-\mathrm{HAw}$ & 0 & 0 & NT & NT \\
\hline $\mathrm{Mn}, \mathrm{SiO}_{3}-\mathrm{HAw}$ & 0 & 0 & NT & NT \\
\hline $\mathrm{Mn}, \mathrm{SiO}_{4}-\mathrm{HAd}$ & 0 & 0 & NT & NT \\
\hline $\mathrm{Mn}, \mathrm{SiO}_{3}-\mathrm{HAd}$ & 0 & 0 & NT & NT \\
\hline
\end{tabular}

${ }^{1}$ Percent of toxic effect after 15 min of incubation; ${ }^{2}$ NT-not toxic.

\section{Conclusions}

Novel manganese and silicate co-substituted apatite materials were synthesized in this study. The study was aimed at comparing the physico-chemical properties of samples depending on the reagent used and the synthesis method. Samples were characterized using PXRD, FTIR, and ssNMR spectroscopy, as well as TEM and WD-XRF. Preliminary biological in vitro tests were also performed. Significant conclusions from these examinations are presented below.

1. Samples obtained using precipitation were nanocrystalline and monophasic. Solid-state samples were microcrystalline and contained secondary phases (impurities), i.e., calcium oxide, calcium hydroxide, and silicocarnotite, which were produced during the sintering process.

2. Manganese and silicon ions were successfully incorporated, as confirmed using WD-XRF and spectroscopic measurements. The substitution efficiency was between $45 \%$ and $95 \%$, depending on the synthesis method and the reagents.

3. A higher efficiency of $\mathrm{Mn}^{2+}$ substitution occurred in the case of precipitation synthesis, while the substitution of silicon was favoured in the solid-state synthesis. In both cases, the yield was better when using silicon acetate instead of sodium metasilicate as a silicon source.

4. The introduction of ions did not significantly affect the crystallinity and unit cell parameters. The degree of crystallinity, as well as the size and shape of the crystals, depended mainly on the synthesis method.

5. According to the Microtox®and Spirotox tests, none of the samples was considered to be toxic. Such promising results may constitute the starting point for further biological research.

Author Contributions: K.S. participated in the synthesis and physicochemical analysis of the samples and wrote the manuscript. A.D. was responsible for the biological tests. J.K. provided the concept of the work, interpreted the results, and helped with the NMR analysis. All authors have contributed to and approved the manuscript.

Funding: This work was supported by a research grant (Project NCN UMO-2016/22/E/ST5/00564) from the National Science Centre, Poland, and a research grant (Project FW23/PM1/18) from Medical University of Warsaw.

Acknowledgments: The TEM studies were performed in the Laboratory of Electron Microscopy, Nencki Institute of Experimental Biology, Warsaw, Poland. We used equipment installed as part of a project sponsored by EU Structural Funds: Centre of Advanced Technology BIM; equipment was purchased for the Laboratory of Biological and Medical Imaging.

Conflicts of Interest: The authors declare no conflict of interest.

\section{References}

1. Vallet-Regi, M.; Gonzales-Calbet, J.M. Calcium phosphates as substitution of bone tissues. Prog. Solid State Chem. 2004, 32, 1-31. [CrossRef]

2. Zhou, H.; Lee, J. Nanoscale hydroxyapatite particles for bone tissue engineering. Acta Biomater. 2011, 7, 2769-2781. [CrossRef] [PubMed]

3. Suchanek, W.; Yoshimura, M. Processing and properties of hydroxyapatite-based biomaterials for use as hard tissue replacement implants. J. Mater. Res. 1998, 13, 94-117. [CrossRef]

4. Kolmas, J.; Krukowski, S.; Laskus, A.; Jurkitewicz, M. Synthetic hydroxyapatite in pharmaceutical applications. Ceram. Int. 2016, 42, 2472-2487. [CrossRef] 
5. Shepherd, J.H.; Shepherd, D.V.; Best, S.M. Substituted hydroxyapatites for bone repair. J. Mater. Sci. Mater. Med. 2012, 23, 2335-2347. [CrossRef] [PubMed]

6. Ratnayake, J.T.B.; Mucalo, M.; Dias, G.J. Substituted hydroxyapatites for bone regeneration: A review of current trends. J. Biomed. Mater. Res. B Appl. Biomater. 2017, 105, 1285-1299. [CrossRef] [PubMed]

7. Supova, M. Substituted hydroxyapatite for biomedical applications: A review. Ceram. Int. 2015, 41, 9203-9231. [CrossRef]

8. Nassif, N.; Martineau, F.; Syzgantseva, O.; Gobeaux, F.; Willinger, M.; Coradin, T.; Cassaignon, S.; Azaïs, T.; Giraud-Guille, M.M. In vivo inspired conditions to synthesize biomimetic hydroxyapatite. Chem. Mater. 2010, 22, 3653-3663. [CrossRef]

9. Roveri, N.; Iafisco, M. Evolving application of biomimetic nanostructured hydroxyapatite. Nanotechnol. Sci. Appl. 2010, 3, 107-125. [CrossRef]

10. Fore, H.; Morton, R.A. Manganese in Bone. Biochem. J. 1952, 51, 598-600. [CrossRef]

11. Jugdaohsingh, R. Silicon and bone health. J. Nutr. Health Aging 2007, 11, 99-110.

12. Armulik, A.; Svineng, G.; Wennerberg, K.; Fassler, R.; Johansson, S. Expression of integrin subunit $\beta 1 B$ in integrin $\beta 1$-deficient GD25 cells does not interfere with $\alpha \mathrm{V} \beta 3$ functions. Exp. Cell Res. 2000, 254, 55-63. [CrossRef]

13. Bracci, B.; Torricelli, T.; Panzavolta, S.; Boanini, E.; Giardino, R.; Bigi, A. Effect of $\mathrm{Mg}^{2+}, \mathrm{Sr}^{2+}$, and $\mathrm{Mn}^{2+}$ on the chemico-physical and in vitro biological properties of calcium phosphate biomimetic coatings. J. Inorg. Biochem. 2009, 103, 1666-1674. [CrossRef]

14. Huang, Y.; Ding, Q.; Han, S.; Yan, Y.; Pang, X. Characterisation, corrosion resistance and in vitro bioactivity of manganese-doped hydroxyapatite films electrodeposited on titanium. J. Mater. Sci. Mater. Med. 2013, 24, 1853-1864. [CrossRef]

15. Saltman, P.D.; Strause, L.G. The role of trace minerals in osteoporosis. J. Am. Coll. Nutr. 1993, 12, 384-389. [CrossRef]

16. Torres, P.M.C.; Vieira, S.I.; Cerqueira, A.R.; Pina, S.; da Cruz Silva, O.A.B.; Abrantes, J.C.C.; Ferreira, J.M.F. Effects of Mn-doping on the structure and biological properties of $\beta$-tricalcium phosphate. J. Inorg. Biochem. 2014, 136, 57-66. [CrossRef]

17. Rico, H.; Gomez-Raso, N.; Revilla, M.; Hernandez, E.R.; Seco, C.; Paez, E.; Crespo, E. Effects on bone loss of manganese alone or with copper supplement in ovariectomized rats. A morphometric and densitomeric study. Eur J. Obstet. Gynecol. Reprod. Biol. 2000, 90, 97-101. [CrossRef]

18. Bae, Y.J.; Kim, M.H. Manganese supplementation improves mineral density of the spine and femur and serum osteocalcin in rats. Biol. Trace Elem. Res. 2008, 124, 28-34. [CrossRef]

19. Medvecky, L.; Stulajterova, R.; Parilak, L.; Trpcevska, J.; Durisin, J.; Barinov, S.M. Influence of manganese on stability and particle growth of hydroxyapatite in simulated body fluid. Colloids Surf. A Physicochem. Eng. Asp. 2006, 281, 221-229. [CrossRef]

20. Bigi, A.; Bracci, B.; Cuisinier, F.; Elkaim, R.; Fini, M.; Mayer, I.; Mihailescu, I.N.; Socol, G.; Sturba, L.; Torricelli, P. Human osteoblast response to pulsed laser deposited calcium phosphate coatings. Biomaterials 2005, 26, 2381-2389. [CrossRef]

21. Kolmas, J.; Jabłoński, M.; Ślósarczyk, A.; Kołodziejski, W. Solid-state NMR study of $\mathrm{Mn}^{2+}$ for $\mathrm{Ca}^{2+}$ substitution in thermally processed hydroxyapatites. J. Am. Ceram. Soc. 2015, 98, 1265-1274. [CrossRef]

22. Mayer, I.; Peto, G.; Karacs, A.; Molnar, G.; Popov, I. Divalent Mn in calcium hydroxyapatite by pulse laser deposition. J. Inorg. Biochem. 2010, 104, 1107-1111. [CrossRef]

23. Sopyan, I.; Ramesh, S.; Nawawi, N.A.; Tampieri, A.; Sprio, S. Effects of manganese doping on properties of sol-gel derived biphasic calcium phosphate ceramics. Ceram. Int. 2011, 37, 3703-3715. [CrossRef]

24. Paluszkiewicz, C.; Ślósarczyk, A.; Pijocha, D.; Sitarz, M.; Bućko, M.; Zima, A.; Chróścicka, A.; Lewandowska-Szumiet, M. Synthesis, structural properties and thermal stability of Mn-doped hydroxyapatite. J. Mol. Struct. 2010, 976, 301-309. [CrossRef]

25. Henstock, J.R.; Canham, L.T.; Anderson, S.I. Silicon: The evolution of its use in biomaterials. Acta Biomater. 2015, 11, 17-26. [CrossRef]

26. Szurkowska, K.; Kolmas, J. Hydroxyapatites enriched in silicon - Bioceramic materials for biomedical and pharmaceutical applications. Prog. Nat. Sci. Mater. 2017, 27, 401-409. [CrossRef]

27. Carlisle, E.M. Silicon: A possible factor in bone calcification. Science 1970, 167, 279-280. [CrossRef]

28. Carlisle, E.M. Silicon: An essential element for the chick. Science 1972, 178, 619-621. [CrossRef] 
29. Reffitt, D.M.; Ogston, N.; Jugdaohsingh, R.; Cheung, H.F.J.; Evans, B.A.J.; Thompson, R.P.H.; Powell, J.J.; Hampson, G.N. Orthosilicic acid stimulates collagen type 1 synthesis and osteoblastic differentiation in human osteoblast-like cells in vitro. Bone 2003, 32, 127-135. [CrossRef]

30. Spector, T.D.; Calomme, M.R.; Anderson, S.H.; Clement, G.; Bevan, L.; Demeester, N.; Swaminathan, R.; Jugdaohsingh, R.; Vanden Berghe, D.A.; Powell, J.J. Choline-stabilized orthosilicic acid supplementation as an adjunct to calcium/vitamin D3 stimulates markers of bone formation in osteopenic females: A randomized, placebo-controlled trial. BMC Musculoskelet. Disord. 2008, 9, 85. [CrossRef]

31. Zhou, S.; Ireland, D.; Brooks, R.A.; Rushton, N.; Best, S. The effects of silicate ions on human osteoblast adhesion, proliferation, and differentiation. J. Biomed. Mater. Res. B Appl. Biomater. 2009, 90, 123-130.

32. Zhao, X.; Wang, T.; Qian, S.; Liu, X.; Sun, J.; Li, B. Silicon-doped titanium dioxide nanotubes promoted bone formation on titanium implants. Int J. Mol. Sci. 2016, 17, 292. [CrossRef]

33. Wang, Q.; Hu, H.; Qiao, Y.; Zhang, Z.; Sun, J. Enhanced performance of osteoblasts by silicon incorporated porous $\mathrm{TiO}_{2}$ coating. J. Mater. Sci. Technol. 2012, 28, 109-117. [CrossRef]

34. Zhou, X.; Moussa, F.M.; Mankoci, S.; Ustriyana, P.; Zhang, N.; Abdelmagid, S.; Molenda, J.; Murphy, W.L.; Safadi, F.F.; Sahai, N. Orthosilicic acid, $\mathrm{Si}(\mathrm{OH})_{4}$, stimulates osteoblast differentiation in vitro by upregulating miR-146a to antagonize NF-kB activation. Acta Biomater. 2016, 39, 192-202. [CrossRef]

35. Gibson, I.R.; Best, S.M.; Bonfield, W. Chemical characterization of silicon-substituted hydroxyapatite. J. Biomed. Mater. Res. 1999, 44, 422-428. [CrossRef]

36. Marchat, D.; Zymelka, M.; Coelho, C.; Gremillard, L.; Joly-Pottuz, L.; Babonneau, F.; Esnouf, C.; Chevalier, J.; Bernache-Assollant, D. Accurate characterization of pure silicon-substituted hydroxyapatite powders synthesized by a new precipitation route. Acta Biomater. 2013, 9, 6992-7004. [CrossRef]

37. Palard, M.; Champion, E.; Foucaud, S. Synthesis of silicated hydroxyapatite $\mathrm{Ca}_{10}\left(\mathrm{PO}_{4}\right)_{6-x}\left(\mathrm{SiO}_{4}\right)_{x}(\mathrm{OH})_{2-x}$. J. Solid State Chem. 2008, 181, 1950-1960. [CrossRef]

38. Aminian, A.; Solati-Hashjin, M.; Samadikuchaksaraei, A.; Bakhshi, F.; Gorjipour, F.; Farzadi, A.; Moztarzadeh, F.; Schmucker, M. Synthesis of silicon-substituted hydroxyapatite by a hydrothermal method with two different phosphorus sources. Ceram. Int. 2011, 37, 1219-1229. [CrossRef]

39. Botelho, C.M.; Brooks, R.A.; Best, S.M.; Lopes, M.A.; Santos, J.D.; Rushton, N.; Bonfield, W. Human osteoblast response to silicon-substituted hydroxyapatite. J. Biomed. Mater. Res. A 2006, 79, 723-730. [CrossRef]

40. Honda, M.; Kikushima, K.; Kawanobe, Y.; Konishim, T.; Mizumoto, M.; Aizawa, M. Enhanced early osteogenic differentiation by silicon-substituted hydroxyapatite ceramics fabricated via ultrasonic spray pyrolysis route. J. Mater. Sci. Mater. Med. 2012, 23, 2923-2932. [CrossRef]

41. Thian, E.S.; Huang, J.; Best, S.M.; Barber, Z.H.; Brooks, R.A.; Rushton, N.; Bonfield, W. The response of osteoblasts to nanocrystalline silicon-substituted hydroxyapatite thin films. Biomaterials 2006, 27, 2692-2698. [CrossRef]

42. Patel, N.; Best, S.M.; Bonfield, W.; Gibson, I.R.; Hing, K.A.; Damien, E.; Revell, P.A. A comparative study on the in vivo behavior of hydroxyapatite and silicon substituted hydroxyapatite granules. J. Mater. Sci. Mater. Med. 2002, 13, 1199-1206. [CrossRef]

43. Patel, N.; Brooks, R.A.; Clarke, M.T.; Lee, P.M.T.; Rushton, N.; Gibson, I.R.; Best, S.M.; Bonfield, W. In vivo assessment of hydroxyapatite and silicate-substituted hydroxyapatite granules using an ovine defect model. J. Mater. Sci. Mater. Med. 2005, 16, 429-440. [CrossRef]

44. Porter, A.E.; Patel, N.; Skepper, J.N.; Best, S.M.; Bonfield, W. Comparison of in vivo dissolution processes in hydroxyapatite and silicon-substituted hydroxyapatite bioceramics. Biomaterials 2003, 24, 4609-4620. [CrossRef]

45. Porter, A.E.; Patel, N.; Skepper, J.N.; Best, S.M.; Bonfield, W. Effect of sintered silicate-substituted hydroxyapatite on remodelling processes at the bone-implant interface. Biomaterials 2004, 25, 3303-3314. [CrossRef]

46. Hing, K.A.; Revell, P.A.; Smith, N.; Buckland, T. Effect of silicon level on rate, quality and progression of bone healing within silicate-substituted porous hydroxyapatite scaffolds. Biomaterials 2006, 27, 5014-5026. [CrossRef]

47. Zhang, E.; Zou, C. Porous titanium and silicon-substituted hydroxyapatite biomodification prepared by a biomimetic process: Characterization and in vivo evaluation. Acta Biomater. 2009, 5, 1732-1741. [CrossRef] 


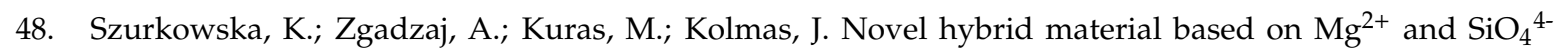
co-substituted nano-hydroxyapatite, alginate and chondroitin sulphate for potential use in biomaterials engineering. Ceram. Int. 2018, 44, 18551-18559. [CrossRef]

49. Nałęcz-Jawecki, G. Spirotox-Spirostomum ambiguum acute toxicity test-10 years of experience. Environ. Toxicol. 2004, 19, 359-364. [CrossRef]

50. Lafon, J.P.; Champion, E.; Bernache-Assollant, D.; Gibert, R.; Danna, A.M. Thermal decomposition of carbonated calcium phosphate apatites. J. Therm. Anal. Calorim. 2003, 72, 1127-1134. [CrossRef]

51. Andreev, A.S.; Bulina, N.V.; Chaikina, M.V.; Prosanov, I.Y.; Terskikh, V.V.; Lapina, O.B. Solid-state NMR and computational insights into the crystal structure of silicocarnotite-based bioceramic materials synthesized mechanochemically. Solid State Nucl. Magn. Reson. 2017, 84, 151-157. [CrossRef]

52. Hayakawa, S.; Kanaya, T.; Tsuru, K.; Shirosaki, Y.; Osaka, A.; Fujii, E.; Kawabata, K.; Gasqueres, G.; Bonhomme, C.; Babonneau, F.; et al. Heterogeneous structure and in vitro degradation behavior of wet-chemically derived nanocrystalline silicon-containing hydroxyapatite particles. Acta Biomater. 2013, 9, 4856-4867. [CrossRef]

53. Chang, M.C.; Tanaka, J. FT-IR study for hydroxyapatite/collagen nanocomposite cross-linked by glutaraldehyde. Biomaterials 2002, 23, 4811-4818. [CrossRef]

54. Merry, J.C.; Gibson, I.R.; Best, S.M.; Bonfield, W. Synthesis and characterization of carbonate hydroxyapatite. J. Mater. Sci. Mater. Med. 1998, 9, 779-783. [CrossRef]

55. Ye, H.; Liu, X.Y.; Hong, H. Characterization of sintered titanium/hydroxyapatite biocomposite using FTIR spectroscopy. J. Mater. Sci. Mater. Med. 2009, 20, 843-850. [CrossRef]

56. Shaltout, A.A.; Allam, M.A.; Moharram, M.A. FTIR spectroscopic, thermal and XRD characterization of hydroxyapatite from new natural sources. Spectrochim. Acta A Mol. Biol. Spectrosc. 2011, 83, 56-60. [CrossRef]

57. Cengiz, B.; Gokce, Y.; Yildiz, N.; Aktas, Z.; Calimli, A. Synthesis and characterization of hydroxyapatite nanoparticles. Colloids Surf. A Physicochem. Eng. Asp. 2008, 322, 29-33. [CrossRef]

58. Tian, T.; Jiang, D.; Zhang, J.; Lin, Q. Synthesis of Si-substituted hydroxyapatite by a wet mechanochemical method. Mater. Sci. Eng. C 2008, 28, 57-63. [CrossRef]

59. Padmanabhan, S.K.; Haq, E.U.; Licciulli, A. Rapid synthesis and characterization of silicon substituted nano hydroxyapatite using microwave irradiation. Curr. Appl. Phys. 2004, 14, 87-92. [CrossRef]

60. Jager, C.; Welzel, T.; Meyer-Zaika, W.; Epple, M. A solid-state NMR investigation of the structure of nanocrystalline hydroxyapatite. Magn. Reson. Chem. 2006, 44, 573-580. [CrossRef]

61. Pourpoint, F.; Gervais, C.; Bonhomme-Coury, L.; Azaïs, T.; Coelho, C.; Mauri, F.; Alonso, B.; Babonneau, F.; Bonhomme, C. Calcium phosphates and hydroxyapatite: Solid-state NMR experiments and first-principles calculations. Appl. Magn. Reson. 2007, 32, 435-457. [CrossRef]

62. Panda, R.N.; Hsieh, M.F.; Chung, R.J.; Chin, T.S. FTIR, XRD, SEM and solid state NMR investigations of carbonate-containing hydroxyapatite nano-particles synthesized by hydroxide-gel technique. J. Phys. Chem. Solids 2003, 64, 193-199. [CrossRef]

63. Magi, M.; Lippmaa, E.; Samoson, A.; Engelhardt, G.; Grimmer, A.R. Solid-state high-resolution silicon-29 chemical shifts in silicates. J. Phys. Chem. 1984, 88, 1518-1522. [CrossRef]

64. Gasqueres, G.; Bonhomme, C.; Maquet, J.; Babonneau, F.; Hayakawa, S.; Kanayab, T.; Osaka, A. Revisiting silicate substituted hydroxyapatite by solid-state NMR. Magn. Reson. Chem. 2008, 46, 342-346. [CrossRef]

65. Gomes, S.; Renaudin, G.; Mesbah, A.; Jallot, E.; Bonhomme, C.; Babonneau, F.; Nedelec, J.M. Thorough analysis of silicon substitution in biphasic calcium phosphate bioceramics: A multi-technique study. Acta Biomater. 2010, 6, 3264-3274. [CrossRef]

66. Schneider, J.; Mastelaro, V.R.; Panepucci, H.; Zanotto, E.D. ${ }^{29}$ Si MAS-NMR studies of $\mathrm{Q}^{\mathrm{n}}$ structural units in metasilicate glasses and their nucleating ability. J. Non-Cryst. Solids 2000, 273, 8-18. [CrossRef]

(C) 2019 by the authors. Licensee MDPI, Basel, Switzerland. This article is an open access article distributed under the terms and conditions of the Creative Commons Attribution (CC BY) license (http://creativecommons.org/licenses/by/4.0/). 